\title{
Structural Reform, Revenue Adequacy And Optimal Tax Assignment In Local Government
}

\section{Lorenzo Robotti}

Department of Economics, Università Politecnica delle Marche and OPERA (Regional Economics Policy Obervatory of Ancona), Italy

\section{Brian Dollery}

School of Business, Economics and Public Policy, and Centre for Local Government, University of New England, Armidale
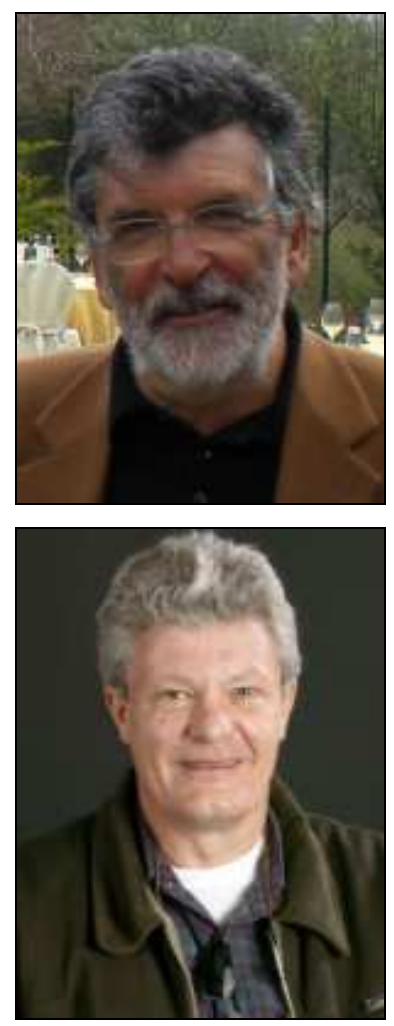

\section{Abstract}

A striking feature of local government reform in many Commonwealth countries has been a heavy reliance on structural reform, often in the form of forced local council amalgamation. This paper argues that the long-run success of structural change in local government hinges on several key factors, not least that voluntary rather than compulsory council mergers have a far greater chance of success. A second key ingredient resides in a high degree of local autonomy in both the composition and 
operation of decentralized governmental functions. A third vital factor lies in ensuring that revenue and tax assignment is sufficient to provide local government with financial autonomy. Finally, adequate powers of taxation need to be accorded to local government and this requires careful consideration of the types of taxes most suited to local government.

Keywords: Decentralisation, local finance, structural reform, tax assignment

\section{Introduction}

The literature on fiscal federalism highlights the various advantages of decentralized administrative functions (Oates 1972). Moreover, this body of thought holds that the economic approach to multi-tiered government can lead to public policies that may improve the economic efficiency of existing systems of government. According to conventional economic theory on fiscal federalism, decentralizing the provision of public services by local governments can enhance social welfare by better matching citizens' preferences for local service provision. In the public choice approach, the decentralization of governmental functions is justified as long as it holds politicians and administrators accountable for their actions. Similarly, the benefits of decentralization can stem from the comparison of governmental units' performances and the resulting competition between different jurisdictions (Shah 2008). In addition, recent theoretical work from a different perspective stresses the value of a federal structure for the performance of local economies (Shah 2006). These positive advantages of multi-tiered government must be set against coordination problems and potentially irresponsible fiscal policies that result from the 'soft' budget constraint often facing lower levels of government in a multi-tiered structure (Dollery and Robotti 2008). Moreover, there is the

problem of the optimal size of local governments. Fully exploiting scale and scope economies in order to reduce the costs of provision of local public services is not always possible. It is thus essential to develop new methods of managing both administrative functions and policies for structural reforms. However, in general, it is very difficult to close the gap with the fiscal equivalence theorem and this is particularly true in the case of multi-task jurisdictions. Therefore, the principle of subsidiarity (which states that the management of public responsibilities should be made by institutions closer to citizens) ought to be matched with the principle of local capacity (which asserts that local governments must have adequate authority, financial resources and administrative and technical competence). These issues form the focus of this paper. 
While at first glance these questions may seem rather too abstract to shed light on the difficulties of running real-world local government systems, recent experience in many Commonwealth countries indicates their vital practical relevance. For instance, a plethora of recent national and state-based inquiries into Australian local government has demonstrated conclusively that, without substantial fiscal transfers, additional powers of taxation or some other form of revenue augmentation, local councils across Australia face financial unsustainability and a growing local infrastructure backlog (Dollery, Byrnes and Crase 2007). Similar if lesser concerns have been voiced in New Zealand local government and have seen an official Local Government Rates Inquiry (2007) call for additional taxes for local councils. In England, the Lyons Inquiry into Local Government also carefully considered the adequacy of local government revenue and recommended significant reform (Lyons 2007).

The paper is divided into six main parts. Section 2 considers the lessons that can be learned from the analysis of alternative models of local government. Section 3 focuses on the decentralization of governmental functions, structural reform and the problem of revenue assignment. Section 4 deals with the question of tax assignment. Section 5 considers the question of the most suitable forms of revenue for local government. Section 6 considers which taxes are best suited to local government, and the paper ends with a brief conclusion in Section 7.

\section{Models of local government and the liberty to choose models}

If real-world jurisdictions do not match the economic principles prescribing both allocative and economic efficiency, then theorists of 'functional federalism' suggest that particular public agencies be created for the provision of specific local public services. Under these circumstances local government policy should promote the creation of this type of public agency. For instance, separate but spatially adjacent local councils may create consortia or engender other forms of partnership for the provision of particular public services, especially those characterised by scope and scale economies. The definition of these independent functional administrations in terms of territorial and functional scope would be different from the scope of existing political jurisdictions, simply because these new administrative bodies would be designed primarily to seek economic advantages (Dollery, Crase and Johnson 2006). Since existing political jurisdictions remain in existence, the implicit risk is that this approach could lead to the 
coexistence of numerous and perhaps excessive overlapping political jurisdictions and agencies, each specializing in providing a specific service. This outcome should be avoided since the multiplication of single-purpose associations increases transaction costs among cooperating governments; furthermore, the heterogeneity amongst the partner local councils complicates program coordination and thus increases the complexity of the system. Both the economic and political literatures on these questions discuss how alternative models of collaboration among local councils in a context of multi-task, multi-level government can assist in formulating policies directed at local government reform. Observed experience in different countries highlights the widespread employment of such models in the real world (Dollery and Robotti 2008). These models differ in terms of the level of operational control (the ability to undertake and administer local service provision) and political control (the capacity to take decisions over the domain and mix of local services) local councils transfer to the new structural entity they form. According to the approach devised by Dollery, Crase and Johnson (2006), we can locate the different models along a bipolar continuum comprising the degree to which political and operational control can be centralized or decentralized between local councils and the new organizational entity. Obviously most models of municipal government shade into each other but, surely, at one end of the spectrum we can find councils which represent fully decentralized political and operational control within the confines of their enabling legislation and, at the other end, we will find amalgamated councils which concede all political and operational control to the larger new entity to which they adhere. From the theoretical point of view, the literature seems to suggest that the choice among the different options provided by the respective national legislatures depends on the desire for variety in the composition of local government service provision (that is, the elasticity of substitution among services), the level of transaction costs and the number of councils participating in collaboration. Depending on the nature of the services and administrative functions local governments are to undertake, and considering the costs and the loss of liberty local communities have to bear, an optimal form of agglomeration or cooperation among councils will be selected (Bartolini and Fiorillo 2008).

Whatever model is chosen, observed international experience leads to the conclusion that local structural reforms work better if inter-municipal cooperation is based largely on voluntary participation. For instance, in Australia, New Zealand and Canada, where structural reforms were seldom carried out with the voluntary support of local 
communities, but almost always occurred under various degrees of state coercion, there is a growing scepticism over the unsatisfactory economic, political and social outcome of council consolidations (Dollery, Garcea and LeSage 2008). Indeed, in some Canadian cases public dislike for the imposed arrangements has led to a counter-reform process that has nullified most of the effects and consequences achieved by amalgamation, with the subsequent loss of credibility by provincial governments. Historical processes loom large in the development of many local governments; municipalities often have unique ethnic, political and sociological features that typically stretch back over long periods of time. Institutional arrangements imposed by central government may thus be doomed to failure (Dollery and Robotti 2008). In sum, the first lesson we can derive from this brief theoretical and empirical analysis is that compulsory forms of association among municipalities appear less effective and less enduring than those based on a voluntary agreement. Voluntary participation may be a necessary condition for success.

\section{Decentralization of functions, structural reforms and revenue assignment}

The second lesson we can draw from theoretical models and international experience derives from the financial foundations of local government partnerships. The models reported in Dollery and Robotti (2008) demonstrate that associations among local councils are enduring and effective if the new administrative entities are financed in a stable manner and secure a substantial income from their 'own' resources. The proper assignment of financial resources is an integral problem connected with decentralization of administrative functions and with structural local reforms, which generally accompany or follow new assignments of services to municipal governments, and the problem of the correct assignment of financial resources is thus fundamental in this context. Indeed, it is fruitless to consider transfers of administrative functions from central to lower tiers of governments without considering at the same time the financial side of the reform (such as which and how many local taxes, which and how many financial transfers from the central government, and so on). If we do not simultaneously consider expenditure and revenue, then this will lead to erroneous policy prescriptions; if structural reform leads to a new and different assignment of functions, then it should be accompanied by a new assignment of financial resources.

One must thus pay attention to the implementation of strategies that assign revenue to the lower levels of government. In this regard Bahl (1999) offers some rough guidelines: 
twelve 'rules' that might help to form a basis of a decentralization strategy. The first rule emphasizes the need for fiscal decentralization to be viewed as a comprehensive system. Bahl (1999, p. 4) observed that:

\begin{abstract}
"Intergovernmental fiscal relations must be thought of as a system, and all pieces in this system must fit together. Implementation should begin with a design of the comprehensive system, and should lay out the plan for each element of the system. A 'one-off' piecemeal reform, encompassing only one element of the system (e.g. central government revenue sharing with local governments), is not likely to fully capture the benefit of decentralization. In fact, it can lead to undesirable outcomes, including larger central deficits and macroeconomic instability. To be sure, a phased-in strategy may be the right way to go to avoid 'reform shock', but countries should follow a comprehensive plan and be prepared to deal with the transition problems during phasein."
\end{abstract}

Several aspects of the financial structure of sub-national governments are prescribed by the theory of fiscal federalism (Oates 1972). The optimal financial structure must incorporate the distribution, income and economic activity of the local population. It must also take into account the assignment of expenditure functions, the evolution of the budgets councils have to manage, and the level of interference of central government in the activity of local communities. With regard to the last aspect, when the interference is greatest, local authorities must rely mostly on transfers from the centre. In contrast, if meddling is limited, sub-national governments ought to finance their budget to a significant extent by locally imposed taxes.

Over the past decade, interference in local government by state or provincial governments seems to have decreased in most developed countries (Dollery, Crase and Johnson 2006). Local governments have been assigned numerous administrative functions and have gained major political power and the ability to defend their citizens' interests against the grasp of the centre. Municipalities have often been encouraged to merge to enhance economic efficiency and political capability. But if decentralization and local political autonomy are to be a reality, it is not sufficient to simply collaborate or amalgamate. Whether or not local collaboration occurs, if local governments do not want to be under the 'financial thumb' of the central government, they need to control their 'own' sources of revenue and acquire resources adequate to finance the functions and expenditures assigned to them. In other words, if local expenditure is expected to grow in a substantial manner because of the assignment of additional responsibilities in such income-elastic areas as health and education, then the pressure on revenue will be great. Local councils must know for certain the resources they need to finance the 
services they have to provide in the future. Above all they will desire a revenue structure that may give them the ability to affect the amount of revenue they receive. A system of grants, if defined in an objective way, may be adequate, but a system of taxes implemented at local level may ensure financial autonomy and control of both sides of the budget. Moreover, a budget financed by 'own' taxes stimulates the responsibility of local politicians and public managers and may also lead to citizens being able to choose the level of expenditure and the quality of services they seek.

Considerations of this kind emphasize the connections that must exist among those being taxed with those receiving the benefits. Indeed, it is a longstanding axiom of the theory of public finance that a series of incentive problems arise when the political system delinks taxation and spending, potentially inducing expenditure decisions that deviate from allocatively efficient levels. ${ }^{1}$

\section{The problem of tax assignment}

The traditional economic approach to federalism provides insight into the problem of the correct assignment of taxation in a multi-level governmental system by prescribing the principle of fiscal equivalence. It focuses on the logic of the benefits received by constituents and the possibilities of taxation being exported to other jurisdictions. In this regard, Oates (1996, p. 36) observed that:

“(1) Lower levels of government...should, as much possible, rely on benefit taxation of mobile economic units, including households and mobile factors of production. (2) To the extent that non-benefit taxes need to be employed on mobile economic units, perhaps for distributive purposes, this should be done at higher level of...government. (3) To the extent that local governments make use of non-benefit taxes, they should employ them on the tax bases that are relatively immobile across local jurisdictions."

Other recommendations of the theory of fiscal federalism refer to concerns over economic efficiency, political efficiency, administrative costs, accountability, the standardization of service provision and horizontal disparities among jurisdictions, vertical imbalances between central and local governments, and buoyancy and stability of the tax yield (Shah 2008). In short, for the conventional model of tax assignment, taxes required for stabilization policy and taxes with a strong redistributive potential should both be the responsibility of central governments. In contrast, levies on relatively

\footnotetext{
${ }^{1}$ Wicksell (1896) and Lindhal (1919) developed this rule. Olson (1969) introduced the 'fiscal equivalence theorem' and Oates (1972) discussed this idea under the heading of 'perfect correspondence'. Following the work of these theorists, deviation from the principle of fiscal correspondence leads to either over or under-provision of local public services.
} 
immobile bases, whose base is relatively evenly distributed and whose yields are likely to be relatively stable, should fall under sub-national/local governments. In practice the best candidates for local taxation are user charges and taxes on real estate. In the case of intermediate levels of government, single-stage sales tax and excises are suitable.

These theoretical prescriptions do not usually provide local governments with adequate fiscal resources relative to the responsibilities they face, especially where they deliver social services. Moreover central governments retain the most lucrative taxes. Accordingly, these prescriptions have "one overwhelming practical consequence, namely, that almost invariably most, if not all, sub-national governments end up with less in 'own revenues'" than the expenditures for which they are responsible (or for which they should be responsible, in terms of the now conventional 'subsidiarity' approach to assigning expenditures)" (Bird 1999, p. 6). It is thus not surprising that the traditional fiscal federalism model provides a poor explanation of tax assignment in the real world, where the assignment that actually prevails reflects the outcome of political bargaining rather than the application of normative economic principles. It is clearly inappropriate for countries in which local governments account for an increasingly large proportion of public spending with lower levels of central government control. If these local governments spend heavily, then they must (in the interests of both economic efficiency and accountability) impose greater taxes than the conventional model permits. In this regard, Bird (1999 p. 5) has argued that: "it is time to rethink the principles underlying the conventional model of tax assignment and to attempt to reconcile principle with emerging practice in a more coherent and sustainable way". These conclusions carry even greater weight for amalgamated local councils (or the central government that forced the amalgamation), who have to demonstrate to their citizens the validity of the merger in terms of significant gains in economic efficiency, independence from central and state governments, political power and transparency.

\section{Which types of fiscal revenues fit well for local government associations?}

The different forms of association ${ }^{2}$ that local governments can implement meet different needs, depending on the type and number of administrative functions that have been decentralized. Local councils can engage in weak forms of association, limited forms of

\footnotetext{
${ }^{2}$ In this context 'association' refers to mechanisms for cooperation and/or shared service delivery by two or more local governments - not to representative associations of councils
} 
collaboration, or consortia providing one or more services. Under these circumstances municipalities maintain their autonomy and continue to be accountable to their citizens for the supply of services even if the provision is delegated to a separate body. In contrast, local councils joining strong forms of associations or even amalgamating give rise to a new government entity: they give up their autonomy and the new entity is then directly accountable to citizens for service provision. Two polar possibilities exist: (1) in weak associations of local councils, revenues that finance service provision are retained by member local councils, and there is a transfer of resources from the members of the association to the association itself in payment for the services supplied; or (2) in stronger forms of association, especially in the case of amalgamation, revenues accrue to the new merged entity, which is directly accountable for both expenditures and their finance.

We will now consider the features of an optimal system of financing the local public budget. In the light of options (1) and (2) above, the features we consider desirable will refer in certain cases to revenues of weak association members or, alternatively, in the event of strong associations, reference will be to revenues of the new governmental entity.

A variety of solutions can assign fiscal revenues to lower levels of government. These solutions differ in the degree of fiscal autonomy with which they provide local governments, their ease of compliance and administration, the fairness and neutrality they are likely to produce, the incentives they provide to foster local economic growth, and the degree of inter-jurisdictional redistribution they can accommodate.

Before discussing the different fiscal sources to be assigned to strong associations or to weak association municipalities, it is useful to set some guidelines for the design of an optimal system of revenue. These guidelines must consider at least two features: (1) local governments ought to administer their taxes on their own; and (2) local fiscal revenue must provide incentives to increase local income and widen the local fiscal base (Weingast 2006). However, such guidelines should also consider the nature of the financial relations existing between central and local governments. McLure (1999) distinguished different cases according to: (1) which level of government chooses the taxes from which local governments receive income; (2) which government defines the tax bases; (3) which government sets the tax rates; and (4) which government administers 
the taxes. From the viewpoint of local fiscal sovereignty, the liberty to set rates is clearly the most important because this is what allows local authorities to significantly affect at the margin the amount of tax yield they collect, and consequently to choose the level and quality of public services they provide. We must thus consider among the desirable characteristics of a local fiscal revenue system the option for a local government to set its own tax rates.

These features are important since they give major revenue independence to local governments and moreover enhance the stability of the association pact and the relations among the member councils (see Palestrini and Polidori 2008). These simple theoretical considerations are useful for choosing between the different methods of assigning fiscal revenues to sub-national governments.

With respect to local fiscal revenues it is possible to distinguish four options: autonomous local taxes, sub-national surcharges, tax sharing and revenue sharing. In general, independent legislation and the administration of own taxes would ensure that local councils and/or their associations maximize local fiscal autonomy and generate incentives to provide market-enhancing public services and to foster local economic growth. Under this system, local governments choose the taxes they impose, define their tax bases, set their tax rates, and manage assessment and the collection of taxation revenue. The limits of this solution may reside in the excessive complexity of the fiscal system, the costs of compliance, or inequities and distortions if jurisdictions choose different taxes or administer the same taxes in different ways. But serious problems of this type could be avoided, without compromising the autonomy of local governments, through agreements among jurisdictions or rules imposed by a higher tier of government. Local surcharges represent another potentially optimal solution. Imposing surcharges would avoid the inequities, distortions and complexities found in the previous case because the definition of the bases and administration of taxes are determined by central government, and local governments retain only the power to fix tax rates. As autonomous taxes, surcharges reward the administrations that carry policies to increase local income. Clearly surcharges must be limited to that portion of the tax base reasonably deemed to arise in the taxing jurisdiction. This may be relatively difficult to realize in some cases (such as corporate tax) and it may be necessary to adopt formulae to share the tax base among affected jurisdictions. Furthermore there is the problem of providing incentives 
for the central government to administer a tax that it does not simply collect (McLure 1999).

Tax sharing and revenue sharing are the most common means of providing resources to local governments, but from our point of view they are less attractive than the previous solutions because they restrict the fiscal autonomy of local jurisdictions; that is, local administrations have autonomy over how to spend a given amount of revenue, but not to alter the amount of financial resources they receive from the central government. Moreover, these types of financial resources provide weak incentives to local governments to boost local economic growth.

In short, autonomous taxes and surcharges represent the optimal methods of financing local governments. They should be thought of as the optimal means of financing the activity of local councils and the associations between them. We thus argue that autonomous taxes are best suited to large municipalities, and especially to strong associations between them. For small municipalities, where the capacity to administer taxes is limited, a system of sub-national surcharges seems more appropriate.

\section{Optimal taxes for local governments}

Section 5 suggested that there are arguments for the assignment of 'own' taxes to local jurisdictions, especially where these are comparatively large. The features of taxes usually proposed to finance local governments are sketched below.

\section{User charges}

User charges are suitable for use by all local governments and ought to be employed whenever possible. These levies are 'fair' in the sense that citizens pay for what they get. The problem is that this type of revenue is not usually adequate to finance major responsibilities decentralized to local jurisdictions. It also has regressive distributional effects.

\section{Environmental levies}

We include environmental levies among the taxes to be considered at local level. Their aim is to compensate for social costs induced by the exploitation of local resources (like the degradation of the local environment, costs suffered by the local population, damage to local public infrastructure, and so on). In common with user charges they generate fairness but, in general, do not provide substantial financial resources to the local budget. 


\section{Property taxes}

According to the traditional theory of tax assignment, property taxes might be considered the most appropriate revenue source for local governments. However these levies typically do not provide adequate revenue flows even though they may ensure incentives to foster local economic growth, because of the relationship that exists between economic development and the value of land, buildings and productive investment (Foster et al. 1980).

\section{Personal income taxes}

It is very difficult for local governments to implement and administer resident-based income taxes because it requires channelling revenues collected at the origin to the jurisdictions where the taxpayers live. This fact requires scrupulous behaviour by governments where the income originates (and surely they have few incentives to maximize the tax yield on behalf of jurisdictions of residence). However a tax on local personal income might be explored (Foster et al. 1980). A suitable solution could be the employment of a flat rate tax to pay for the general benefits of public expenditure. Benefits in terms of amount of revenue, revenue growth and incentives to increase local income are inherent in personal income taxes, but the system is too complex.

\section{Sales taxes}

In most countries the value-added tax (VAT) or consumption tax is the principal general sales tax levied by the central government. Whether consumption taxes are suitable for use by local governments has long been controversial. In the past, theorists emphasized high administrative and compliance costs, and the problems arising from cross-border trade, but in reality the problem lay in the reluctance of central governments to lose any control over this tax. After the decentralization of major governmental expenditure functions in many countries the need of financial revenue outweighed these objections and in some countries sales taxes are levied at regional level (as in the United States) or at central and regional levels (as in Canada). ${ }^{3}$

The application of sales taxes at regional level has not been without problems, but where the standard of tax administration was sufficiently high it was possible to operate a sales tax successfully, at least for large regional governments with close cooperation between the different levels of fiscal authorities. The experience of some countries shows that it is

\footnotetext{
${ }^{3}$ For a discussion of several country cases, see Bird (1999) and McLure (1999).
} 
perfectly feasible to operate a sales tax at the regional level. ${ }^{4}$ However it is doubtful whether this tax might be employed at a lower level and therefore might finance the budget of local council associations.

\section{Taxes on business}

The economic rationale for local business taxation resides in the application of the benefit principle: firms should pay for the benefits they receive from local public expenditure. Where possible services benefiting specific enterprises should be financed by user charges but when this solution is not feasible, some form of broad-based general tax on business activities should be levied.

At present the principal forms of business taxation that could be levied at local level are threefold: a corporate income tax (CIT), a payroll tax and a turnover tax. All three possess problems that make them unattractive as a revenue source, but the financial political realities of governing are such that many sub-national governments will wish to impose them anyway (Bird 1999). It is generally known that a major disadvantage of a local corporation income tax is the difficulty of determining the geographical source of profit. Because of the economic interdependence among activities in various jurisdictions, it is often impossible to isolate the income source of a company whose branches are operating in two or more jurisdictions (McLure 1999). A second wellknown disadvantage is the distortions in the territorial allocation of investment and enterprise location that this tax may induce; the levy of the tax by local governments without uniformity can trigger forms of destructive 'beggar-thy-neighbour' competition among jurisdictions and cause severe problems to the budgets of municipalities.

Both the turnover tax and the payroll tax present much the same problems. While the tax bases for these taxes are easier to determine and to assign than in the case of a local CIT, the problem of distortions remains and, in addition, there is the problem of tax exporting. Payroll taxes are already utilized in many countries to finance social insurance.

In conclusion, it is difficult to find support for taxing any one input, whether labour or capital. Perhaps a broad-based business tax could be levied on the added value distributed by enterprises. Such a tax would be neutral to the factor mix and, if nothing else, could provide substantial additional revenue to the budget.

\footnotetext{
${ }^{4}$ Clearly a common base would add more efficiency to the system, but this degree of convergence is not essential.
} 
The imposition of a business value tax (BTV) has been suggested by Bird (1999). Compared with the traditional VAT, the BTV has three important distinguishing features: "First, it is levied on income, not consumption: that is, it is imposed on the sum of profits and wages, or to put in another way, on investments as well as on consumption. Second, it is imposed on production, not consumption: that is, it is imposed on an origin not destination basis and hence, in effect, taxes exports and not imports. Third, it is assessed by the subtraction (or addition) method on the basis of annual accounts rather than on a transaction or invoice-credit method" (Bird 1999, p. 33) ${ }^{5}$. Moreover "as a replacement for existing sub-national business taxes, a BVT would improve sub-national tax systems in several ways. First, it would be more neutral and would not favour certain investment over others. Second, it would be less susceptible to base erosion especially relative to CITs, since, for example, the tax rate would be lower and the base would be unaffected by such matters as the extent of debt financing. Third, although more stable than CIT in revenue terms, a BVT should nonetheless be more sensitive to cyclical realities than most other forms of business tax" (Bird 1999, pp. 33-34).

These arguments are not exclusively theoretical, since variants of such a tax have already been implemented in some countries: In Italy, at regional level, IRAP is applied on a base including wages, profit and interests. In France the taxe professionelle unique is levied by Communes, Régions and Départments and accounts about $20 \%$ of local revenues. It was originally worded in an analogous manner to BTV, but wages have been gradually exempted from the base. In Germany the communal tax Gewerbesteuer at present has the nature of a levy on the added value distributed by the enterprise to production factors, excluding workers.

Would a local BVT make sense? Following Bird, it might be sensible in large jurisdictions, which could reasonably be expected to adequately assess and collect the tax, and would have the incentive to do so because of the size of the local base that could be tapped.

\section{Concluding Remarks}

One of the principal themes that flow through the economic literature on structural reforms concerns the usefulness of matching the principle of subsidiarity with the principle of fitness: the policy of decentralizing major administrative functions to

\footnotetext{
${ }^{5}$ Studenski (1940) proposed a VAT very close to the BVT discussed in this paragraph.
} 
municipalities must match with the arrangement of institutional tools that allow local communities to exploit in full the potentials placed at their disposal by the central government and to serve their citizens in an optimal manner. The experiences of different countries show that a set of alternative models of collaboration among local councils is available and can help to formulate policies directed at local government reform. Local councils have to choose the form of collaboration that fits best with the functions transferred to them by the central government. The principle that we have emphasized in this respect is 'voluntariness': if associations among local councils (either limited or extensive) are to be effective and to endure they ought not to be compulsory, but chosen by the local councils themselves.

A second principle we draw from theoretical models and international experience focuses on the forms of financing local council associations: if local governments have significant expenditure responsibilities, they have strong incentives to organize in associational arrangements. But if association is to be effective and enduring then the new entity must be financed in a stable and predictable manner and should generate a substantial proportion of its 'own' resources. In this respect, in the final part of this paper we sketched the features of taxes that might be proposed to finance the budgets of local government associations.

One tax seems to dominate among the different types of financial levies: a new form of local business tax called BVT, a tax that might at first be considered as a replacement for inefficient and undesirable sub-national CITs. Positive experience in some jurisdictions seems to suggest that the path is clear for the application of this tax at local level, at least in large jurisdictions, as local government associations should be in ideal circumstances. If this view has validity, the present system of local taxation could change in a substantial way. The result would be a family of VATs with a standard VAT imposed at the central government level, a VAT imposed at regional level and a BVT (essentially an income-type VAT) levied on all VAT payees by larger local governments. In addition, all sub-national levels of government should apply appropriate user charges, traditional property taxes and tax sales. Such a package surely will not solve all the problems of establishing sound and workable tax regimes for the associations among local councils, but it seems promising and may at least lead to fruitful debate. 


\section{References}

Bahl, R. 1999, 'Implementation rules for fiscal decentralization', mimeo, International Studies Program School of Policy Studies, Georgia State University, Atlanta.

Bahl, R. and Martinez-Vasquez, J. 2006, 'Sequencing fiscal decentralization', Policy Research Working Paper no. 3914, The World Bank, Washington, DC.

Bartolini, D. and Fiorillo, F. 2008, 'Local council partnerships: a theoretical approach' in Dollery and Robotti, paper presented to the Seminario di Departmento, University Politechnica delle Marche, Ancona, Italy, 11 May 2006.

Bird, R. M. 1999, Rethinking subnational taxes: a new look at tax assignment, International Monetary Fund, Working Paper no.99/165, Washington, DC.

Dollery, B. E., Byrnes, J. D. and Crase, L. 2007, 'Too tough a nut: Determining financial sustainability in Australian local government', Australasian Journal of Regional Studies, 13(2), pp. 110-133.

Dollery, B. E., Crase, L. and Johnson, A. K. 2006, Australian local government economics, University of New South Wales Press, Sydney.

Dollery, B. E., Garcea, J. and LeSage, E. 2008, Local government reform: A comparative analysis of advanced Anglo-America countries, Edward Elgar, Cheltenham.

Dollery, B. E. and Robotti L. (eds) 2008, The theory and practice of local government reform, Edward Elgar, Cheltenham.

Foster, C. D., Jackman R. and Perlman M. 1980, Local government finance in a unitary state, Allen \& Unwin, London.

Garcea, J. and LeSage, E. 2008, 'Local government reform in Canada', in Dollery, Garcea and LeSage (eds.), Local Government Reform: A Comparative Analysis of Advanced AngloAmerican Countries, Edward Elgar, Cheltenham.

Lindhal, E. 1919, 'Just taxation - a positive solution', in R.A. Musgrave, R. A. and Peacock, A. T. (eds), 1958, Classics in the theory of public finance, McMillan, London.

Local Government Rates Inquiry Panel (New Zealand), 2007, Funding local government, Report of the Local Government Rates Inquiry, Wellington.

Lyons, M. 2007, Lyons Inquiry into local government: Place-shaping: A shared ambition for the future of local government, HMSO, London.

McLure, C. E 1999, 'The tax assignment problem: conceptual and administrative considerations in achieving subnational fiscal autonomy', mimeo, World Bank, Washington, DC.

Oates, W. 1972, Fiscal Federalism, Harcourt Brace Jovanovich, New York.

Oates, W. 1996, 'Taxation in a federal system: the tax assignment problem', Public Economic Review, vol. 1, pp. 35-60.

Olson, M. 1969, "The principle of "fiscal equivalence": the division of responsibilities among different levels of government', American Economic Review, Vol. 59, no. 2, Papers and 
Proceedings of the Eighty-first Annual Meeting of the American Economic Association (May, 1969), pp. 479-487.

Palestrini, A. and Polidori, P. 2008, 'A theoretical model of shared service arrangements in local government', in Dollery, B. E. and Robotti L. (eds) 2008, The theory and practice of local government reform, Edward Elgar, Cheltenham.

Shah, A. (ed.) 2006, Local governance in developing countries, World Bank, Washington, DC.

Shah, A. (ed.) 2008, Macro federalism and local finance, World Bank, Washington, DC.

Studenski, P. 1940, 'Towards a theory of business taxation', The Journal of Political Economy, Vol. 48, no. 5, pp. 621-654.

Weingast, B. R 2006, 'Second generation fiscal federalism: implications for decentralized democratic governance and economic development', Discussion draft, Hoover Institution, Stanford.

Wicksell, K. 1896, 'A new principle of just taxation', Musgrave, R. A \& Peacock, A. T. (eds), 1958, Classics in the theory of public finance, McMillan, London. 